\title{
ATmega2560 mikrokontroller alapú jármü mechanikai hullámként terjedő rezgés vezérlése Bluetooth szabvány alapján
}

\author{
Papp Jácint \\ Informatikai Tanszék \\ Debreceni Egyetem, Informatika Kar \\ Debrecen, Magyarország \\ jacint19960713@gmail.com
}

\author{
Beatrix Papp \\ London South Bank \\ University \\ School of Law and Social \\ Sciences, \\ London, United Kingdom \\ pappb@1sbu.ac.uk
}

\author{
Erdei Timotei István \\ Mechatronikai Tanszék \\ Debreceni Egyetem, Müszaki Kar \\ Debrecen, Magyarország \\ timoteierdei@eng.unideb.hu
}

\begin{abstract}
Absztrakt-Mivel többféle kommunikációs csatorna is felhasználható az üzenetek továbbítására így, a befogadó szempontjából napjainkban a fő szempont az üzenet minél gyorsabban történő érkezése, a minél pontosabb eredeti alak és érték megtartása. A hangalapú jelek az elektromágneses jelekhez képest lassabban jutnak el a célig, $s$ míg a hangbevitelnél jóval nehezebb a folyamatos értéket megtartani, azt jóval könnyebb a másik említett módon. A jelek a távolság függvényében rendszerint torzulnak, eltérnek eredeti értéküktől, míg egy hangjelet sokkal több minden zavarhat, addig egy elektromágneses jelet kevesebb minden, emiatt a továbbfejlesztési kísérletben a hang alapú feldolgozás mellet, megjelenik a Bluetooth technológia alapú jeltovábbítás az értékek továbbítása érdekében.
\end{abstract}

Kulcsszavak-Arduino; LCD kijelzö; Hangszenzor; DC motor; Vezérlés; Kommunikáció

\section{BEVEZETŐ}

A projekt egy korábbi állomásához mérten, került továbbfejlesztésre. A hangalapú jeltovábbítást továbbra is megtartva a törekvés fö célja egy második, más elven müködő érték átadásra alkalmas csatorna bevezetése és használata. Továbbra is figyelemmel tartva azt a szempontot, hogy nem áll rendelkezésre internet vagy WIFI kapcsolati lehetőség.

Ezeken felül még az is nagy szerepkört tölt be, hogy könnyebben kezelhető és kimeneteit tekintve felhasználó barát legyen a jármü.

A Bluetooth technológia melletti döntés annak is köszönhetö, hogy rengeteg okostelefon rendelkezik ezzel a funkcióval és mely napjainkban elég elterjedt eszköz, így még megspórolható egy külön erre a célra kifejlesztendő távirányító is. A kutatás/fejlesztésnek a Debreceni Egyetem adott otthont [17].

\section{A TERVEZÉS FŐBB SZEMPONTJAI}

$\mathrm{Az}$ eszközök kiválasztása az újabb feladatoknak és elvárásoknak megfelelően történt.
Megemlítendő törekvési cél még továbbá a távolság érzékelés megvalósítása, kiküszöbölve az esetleges egyenes irányi ütközéseket. Azaz a szenzornak legalább annyira jól és pontosan kell érzékelnie a távolságot, hogy a jármü biztonságosan megállhasson, mielőtt még nekiütközne az útjában elhelyezkedő akadálynak.

\section{MÜKÖDÉSI ELV}

A jármủ működési elve a következő módon írható le. A bekapcsolást követően egy kezdeti, három másodperces hangszint felmérés után a jel küldése a felfogó egységek felé kétféleképpen történhet, vagy hang alapú és a hangérzékelő szenzoron keresztül vagy Bluetooth kapcsolódáson keresztül és annak a csatornáján való jelküldéssel.

Ez után a lépés után már a jelértelmezési rész következik, ahol a logikai és vezérlő egység kikövetkezteti a végrehajtandó müveleteket, majd annak a végrehajtásra és az eközben való érzékelésekre kerül sor. Folyamatábrán szemléltetve megtekinthető a müködés főbb elválasztó lépései és fázisai, ahogy az 1 . ábrán látható.

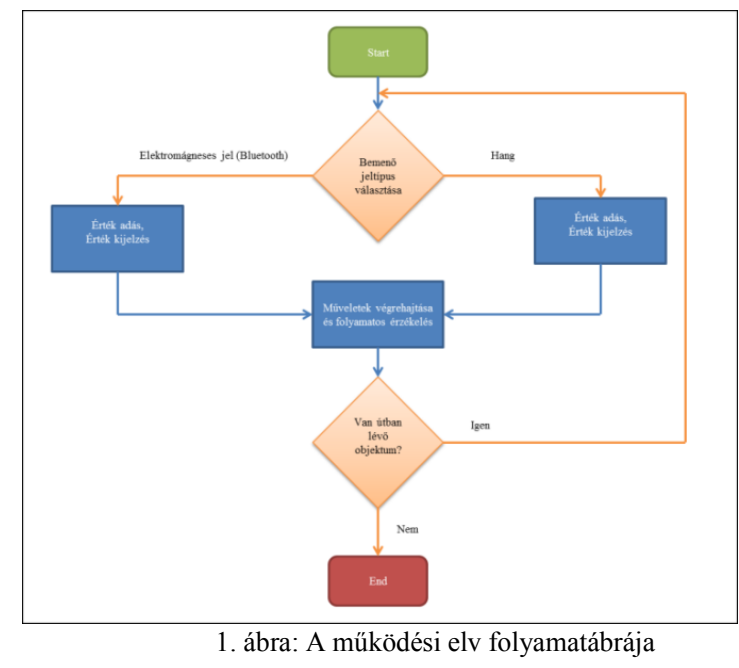




\section{A MOZGÓ JÁRMÜ TERVEZÉSE}

Az alapvázon elhelyezkedő elemek elrendezése törekszik a súly elosztására. A jármü súlya $0,8 \mathrm{~kg}$ a méretei azonban megmaradtak és még megfelel a $25 \mathrm{~cm} \times 30 \mathrm{~cm}$ x $25 \mathrm{~cm}$ téglatest kritériumnak. Mindazonáltal még figyelembe kellet venni az egyes modulok közti távolságot. Az elrendezéshez nagyon hasonló fizikai kapcsolási terv segít szemléltetni, amit a 2. ábra mutat be, mely a Fritzing[1] és a Gimp[2] szoftverekkel készült.

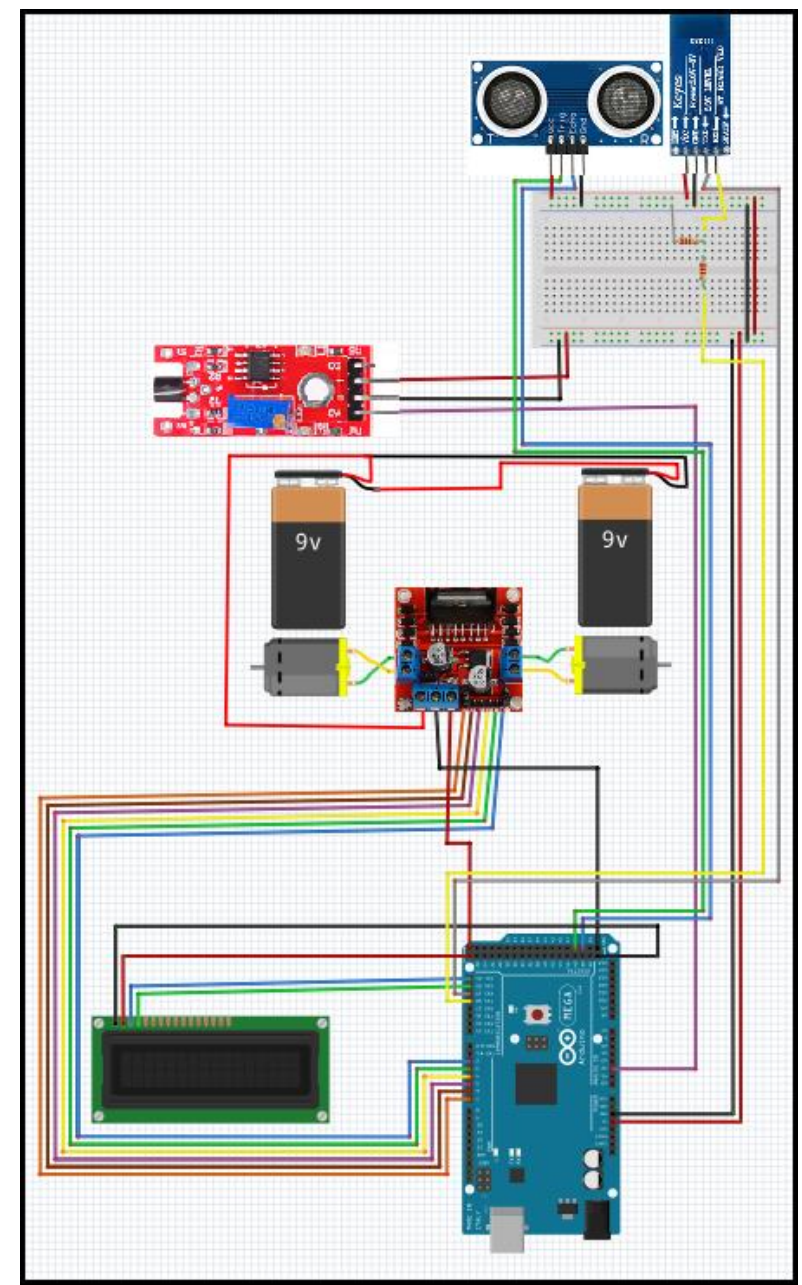

2. ábra:A fizikai kapcsolási terv

A fő vezérlő egység az Arduino Mega 2560 Rev3[3] (továbbiakban $\mathrm{AM}$ ) a nagy moduláris támogatásnak és a könnyen kezelhető és érthető kódrendszere miatt került választása. Maga a programkód az Arduino IDE[4]-ben került megírásra. Müködése, mint a többi Arduinos eszköznek, úgy ennek is szekvenciális és ismétlődő.

Az AM egység, mint a többi ilyen Arduino vezérlő nem képes a DC motorok[5] meghajtására öneröből. Ehhez továbbra is egy másik, motorokat vezérlő egységre van szükség, amit az L298H[6] lát el, ami képes az Arduino PWM[7][8] kimeneteit is kezelni.

Energia ellátása 2 darab 9 Voltos elemmel történik, mely a motorvezérlő egységbe kapcsolódnak, aminek az egyik funkciója az is, hogy ha több feszültséget kap, mint amennyi a motorok meghajtásához szükséges, azt képes továbbítani más modulok energia ellátására.

Egy HC-06[9] Bluetooth modul teszi lehetővé a jármühöz való csatlakozást ezen a csatornán. A modul kapott-küldött jeleket azonban nem a müködési 5Volt-os feszültségen támogatja, hanem a 3,3Volt-os feszültséget. Azonban az AM jelküldő kimenetei 5Volt-ot támogatnak, így le kellet redukálni 3,3Volt-ra a kimeneti feszültségüket, amit két, sorban kötött ellenállással érhető el. Az ellenállások mértéke kiszámítható az (1.) képlettel.

$$
V_{k i}=V_{b e} *\left(\frac{R 2}{R 1+R 2}\right)
$$

Az ellenállások mértéke egy $10 \mathrm{k} \Omega(\mathrm{R} 1)$ és egy20k $\Omega(\mathrm{R} 2)$ ellenállás megfelelöen összekötve.

Ezeken felül még beszerelésre került egy 2004A LCD kijelző[10], aminek müködtetéséhez elegendő négy kimeneti port, egy távolság mérő szenzor[11] is helyet kapott a váz elején, és természetesen a hangszenzor is a jármü részét képezi. A 3. ábra a zajfelmérö funkció kódrészletét mutatja be.

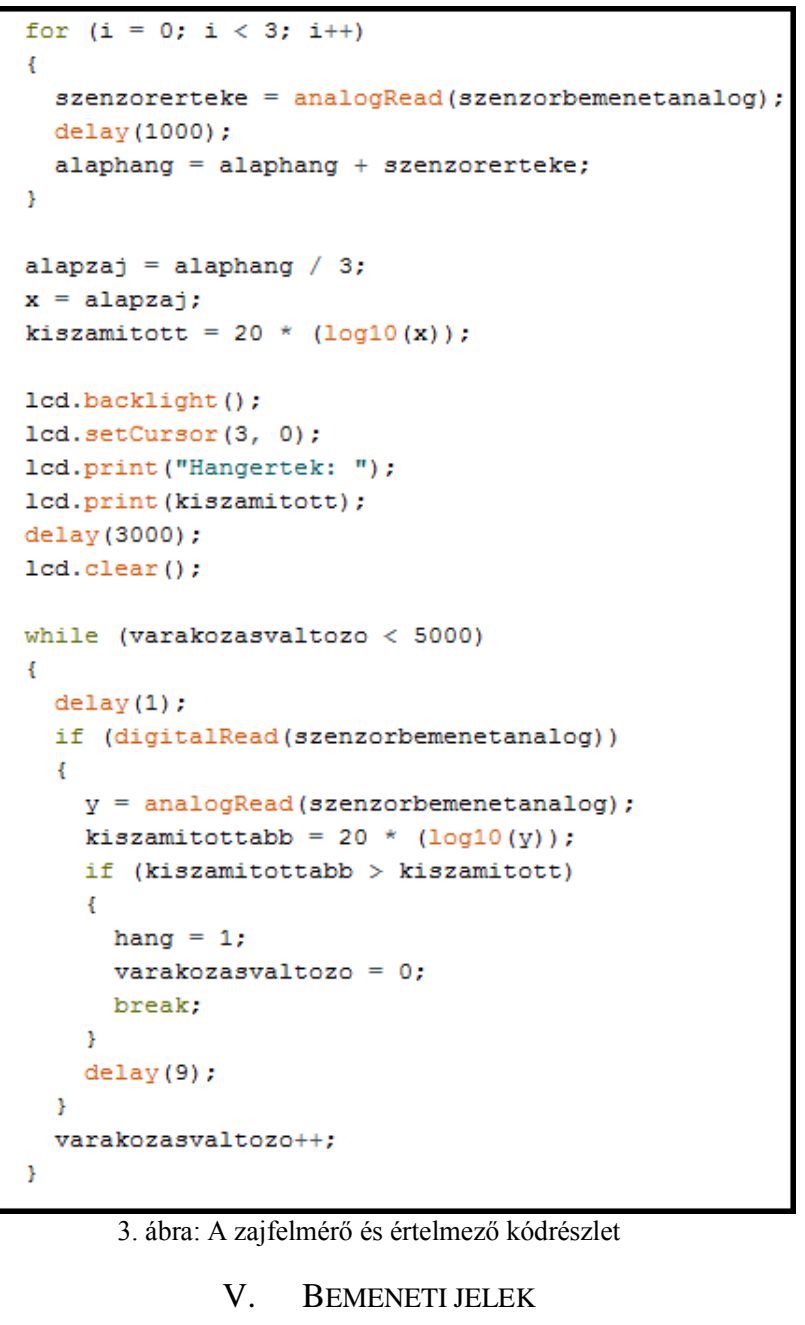

A hangalapú bemeneti jel képlete továbbra is a (2.) képletet felhasználva kapható meg. A referencia hang az $\mathrm{X}_{0} 1$ - 
nek lett választva, az emberi érzékelő küszöbnek megfelelően [12][13].

$$
X_{d b}=20 * \log _{10} *\left(\frac{X}{X_{0}}\right)
$$

Ezen felül még a bluetooth csatornán bejövő jel is értelmezésre kerül, amit a telefonról egy applikáció segítségével tudunk elküldeni a vezérlő egységnek, miután a két eszköz összekapcsolódott.

\section{TELEFONOS APPLIKÁCIÓ}

A bluetooth-al történő kapcsolódást a készülékhez egy applikáció segítségével érhetjük el, amely az MIT App Inventor 2-ben [14] került megírásra Android operációs rendszerre. A kódjának vizualizált képét a 4. ábra szemlélteti.

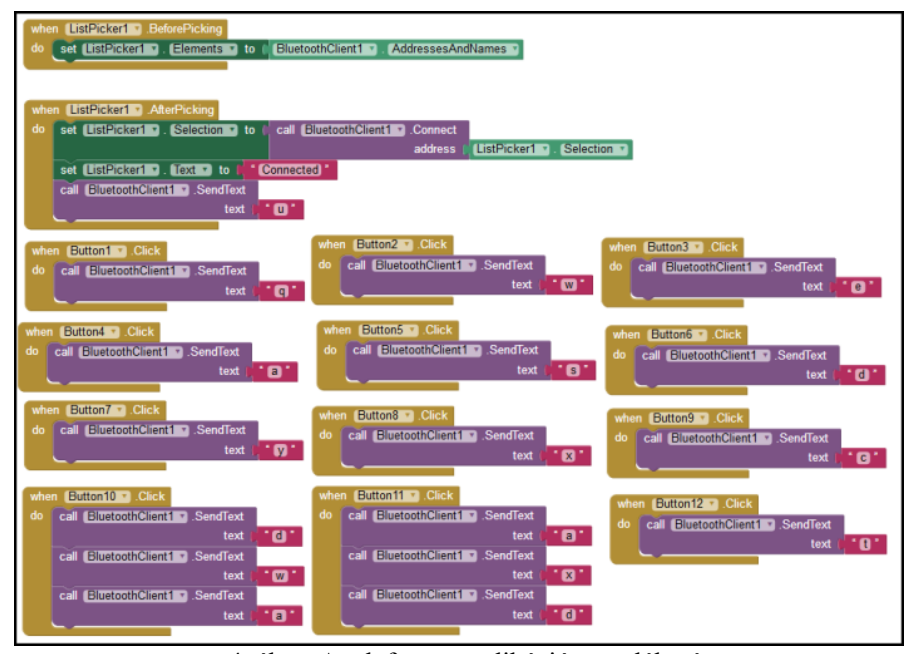

4. ábra: A telefonos applikáció szemléltetése

A jelküldésre szolgáló gombok egyenként más és más üzeneteket küldenek az érzékelő egység felé, amit átad a vezérlő modulnak értelmezésre. Ebben a kódmezőben tudjuk beállítani az elöre eltárolt útvonalakat is, amelyek az útvonal gombokhoz társulnak.

A telefonon megjelenő szöveggel és képekkel illusztrált irányok jól felismerhetőek, valamint a lehetséges útvonalak és a véglegesítés funkciók elrendezését mutatja be az 5 . ábra.

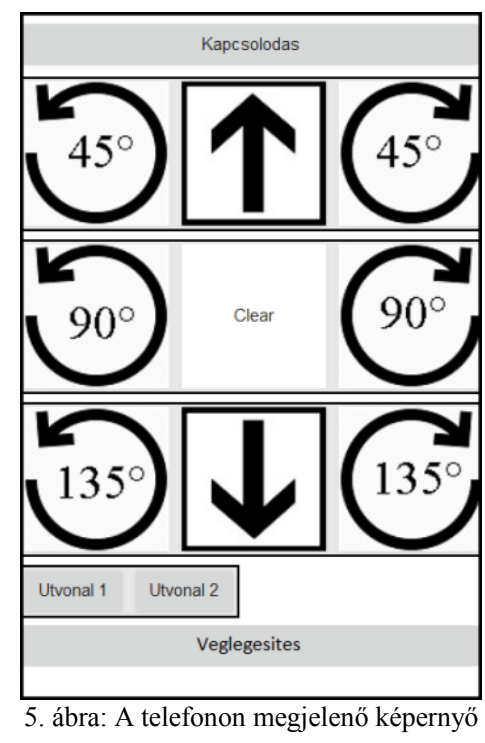

Helyet kapott még egy bevitt parancsokat törlö gomb is, mely megnyomásával törli az addig bevitt adatokat, esetleges félrenyomás vagy szánt szándék következtében. A parancsok törlése még akkor is elérhető, ha a maximálisan végrehajtható utasítások számát meghaladja a bevitt parancsok száma.

$\mathrm{Az}$ értékek bevitele egyszeri, gombhoz való hozzáérintéssel érhető el, melyek sorban kezdik el feltölteni a végrehajtandó parancsok helyeit. Lehetőség van még az útvonal funkciók után is hozzáadni más irányváltoztató utasításokat is. Fontos, hogy a végrehajtandó útvonalterv nyugtázása a „Veglegesites” gombsegítségével történik, csak ezután a gomb lenyomása után indul el a parancsok végrehajtása, az ilyen típusú adat küldése után.

\section{VISSZAJELZÉSEK}

$\mathrm{Az}$ ezelötti a 6 diódából álló visszajelző rendszer hiányosságait figyelembe véve, mint azt, hogy körülményes volt kezelni, leolvasni róla az értékeket. Kiemelve azt, hogy szinte teljes egészében lefedett egy próbapanelt, emellett még sok kimeneti portot is igénybe vett, ezt felváltotta egy folyadékkristályos kijelzö. A müködéséhez szükséges portjainak száma kevesebb kimenetet igényel és az adatok leolvasása így jóval egyszerübb és kényelmesebb lett, és megtartotta azt a tulajdonságát is, hogy a sötétben is jól látszódik.

A kijelző már a jármű bekapcsolásával együtt aktivizálódik, és a zajszint felmérése után már ki is jelzi az alapzaj értékét.

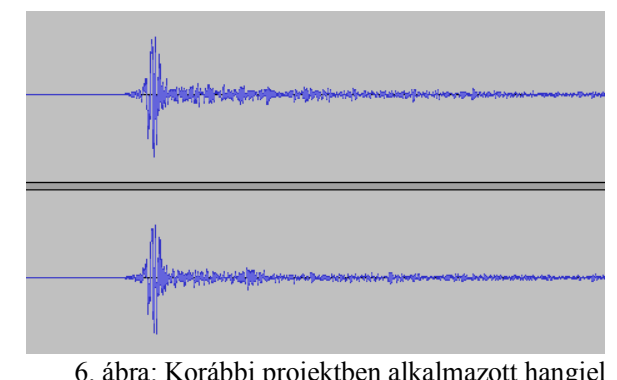


Ezután a kiválasztott beviteli módnak megfelelően jelzi ki módválasztó üzenetet. Amennyiben hangalapú jel lesz a bementi jel, úgy hangjelet vár a hangérzékelő szenzoron keresztül és a „Hangertekes” kifejezést írja a képernyőre. Második beviteli módja választása esetén a „Tavutasitas” kifejezést írja a képernyőre, majd pedig vár, hogy egy eszköz csatlakozzon a moduljához. Amint létrejött a sikeres kapcsolódás a monitoron a „Kapcsolodva” felirat jelenik meg és kezdődhet az utasítások betáplálása.

A mozgási folyamat megkezdése előtt még megjelenítődik az addig betáplált utasítások listája egyfajta végső ellenőrzésként, amennyiben ez valamilyen okból nem egyezne a kívánt eredménnyel, abban az esetben még gyorsan kikapcsolható az eszköz, az AM-n található piros gombbal. A képernyőt müködés közben a 7 . ábra mutatja be.

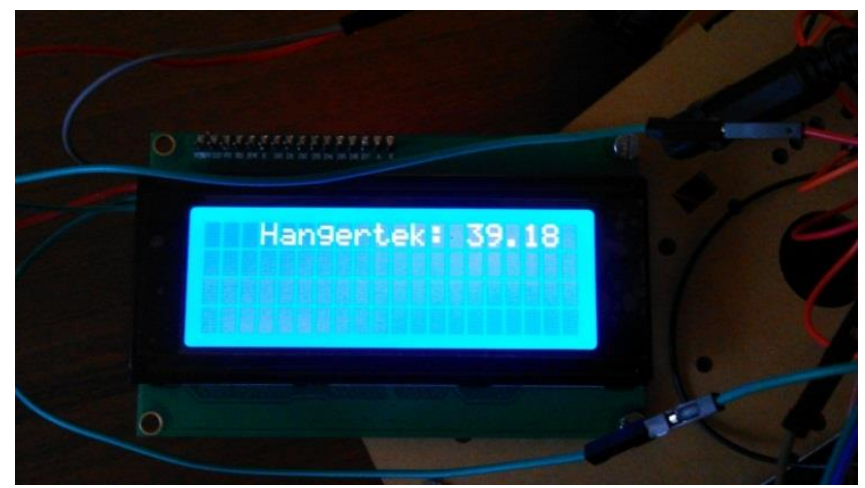

7. ábra: A kijelző müködés közben

\section{HELYZETVÁLTOZTATÁs}

Amennyiben sikeresen megtörtént az adatbevitel, úgy elkezdődik a parancsok szekvenciális végrehajtása. Ezen tevékenység közben a jármü már nincs tekintettel az újonnan érkező jelekre és a test elején elhelyezkedő távolság mérő szenzor figyeli, ha esetlegesen a jármű mozgása során valamilyen akadály állná el az útját. Ha ez a távolság egy bizonyos türéshatáron belül van, az kényszerleállítást hajt végre a motorokon, így megállítva a mozgó egységet és ezzel elkerülve az ütközést [15].

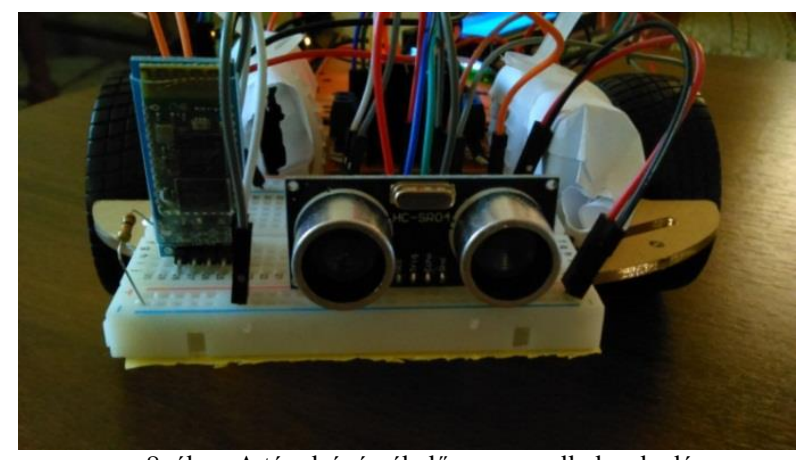

8. ábra: A távolságérzékelő szenzor elhelyezkedése

A mozgások végrehajtása szakaszosan és folytonosan is történhet. Míg kanyarodások rögzített ideig tartanak, ám a helyzetváltoztatások, mint az előrehaladás, ha egymás után érkező, ugyanolyan irányba történő jelként érkezik, akkor folyamatos marad.

A helyzetváltoztatásra szolgáló irányparancsok és az azokhoz hozzárendelt számszerüsített értékeket a Táblázat I. jeleníti meg.

\section{TÁBLÁZAT I. MOZGÁSI PARAMÉTEREK}

\begin{tabular}{|c|c|}
\hline Parancs & változó értéke \\
\hline $\begin{array}{c}\text { Balra fordulás } 45 \\
\text { fokkal }\end{array}$ & 1 \\
\hline Elörehaladás & 3 \\
\hline $\begin{array}{c}\text { Jobbra fordulás } 45 \\
\text { fokkal }\end{array}$ & 4 \\
\hline $\begin{array}{c}\text { Balra fordulás } 90 \\
\text { fokkal }\end{array}$ & 5 \\
\hline $\begin{array}{c}\text { Jobbra fordulás } 90 \\
\text { fokkal }\end{array}$ & 6 \\
\hline $\begin{array}{c}\text { Balra fordulás } 135 \\
\text { fokkal }\end{array}$ & 7 \\
\hline Hátramenet & 8 \\
\hline $\begin{array}{c}\text { Jobbra fordulás } 135 \\
\text { fokkal }\end{array}$ & \\
\hline
\end{tabular}

\section{PARANCS ÁTALAKÍTÓ PROGRAM}

A hangalapú jelek bevitelekor, habár már sokkal egyszerübb, még kialakításra került egy segítő program a Code:Blocks IDE-ben [16] lett megírva, amely a számszerüsített utasításokból egy szöveges kimenetet tartalmazó ablakban jeleníti meg a kimenetet.

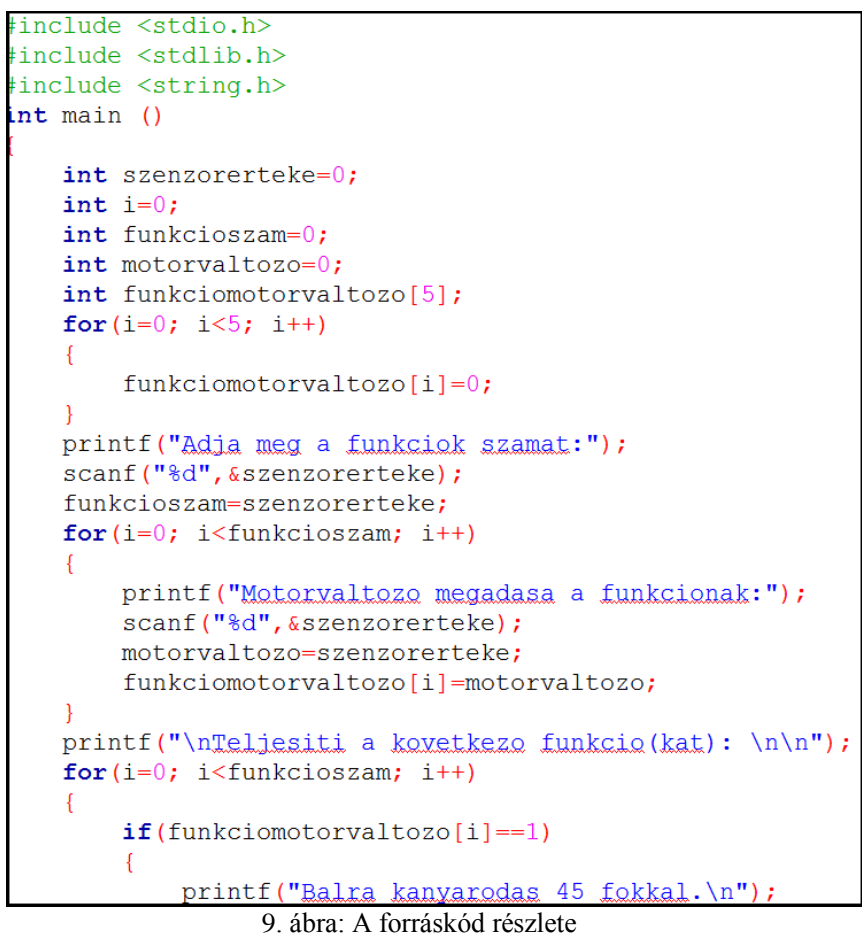


A üzenetet a felhasználók szövegként tudják értelmezni. A kimeneten az egymás után sorban végrehajtódó folyamatok egymás alatt jelennek meg, azonban amikor több folyamat ugyanazt hajtaná végre egymás utáni sorrendben, azok egybevonásra kerülnek, amint azt a 9. ábra szemlélteti.

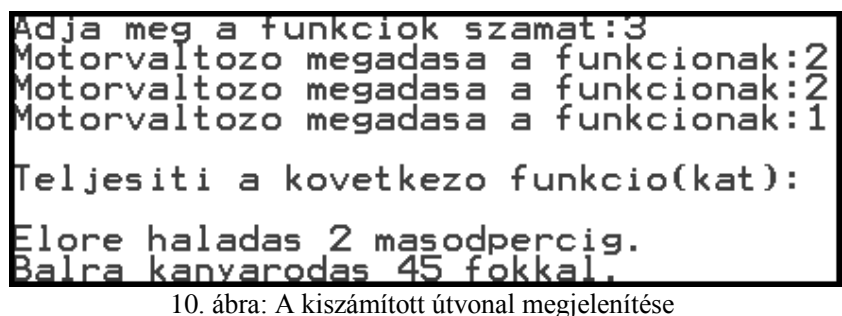

X. TESZTELÉSEK

A mozgó jármű előrehaladása és hátrameneti mozgása során mért eredményeket a következő Táblázat II. szemlélteti.

\section{TÁBLÁZAT II. A MÉRÉS EREDMÉNYEI}

\begin{tabular}{|c|c|c|}
\hline Irány & $\begin{array}{c}\text { analogWrite } \\
\text { értéke }\end{array}$ & Átlagsebesség(m/s) \\
\hline Előrehaladás & 70 & 0,82 \\
\hline Előrehaladás & 140 & 1,12 \\
\hline Elörehaladás & 210 & 1,4 \\
\hline Hátramenet & 70 & 0.79 \\
\hline Hátramenet & 140 & 1,10 \\
\hline Hátramenet & 210 & 1,38 \\
\hline
\end{tabular}

A mozgási tevékenységek elvégzése közben, amennyiben nem megfelelö helyzet állna elö, miszerint nem a megfelelő irányba megy, túl sokáig megy, esetlegesen teljesen mást csinál, mint az elvárt állapotsor, úgy az AM-en elhelyezkedő piros gombbal újraindítható a jármü. Ezen müvelet után, mivel a kódsorában korán deklarálva van az alapállapot, így az azonnal megáll.

A tesztelések során, azonban semmiféle olyan eset nem történt mely során bármi is indokolta volna ennek a müvelet végrehajtását, de tesztelésre került ez a funkció is, megfelelö eredménnyel.

Megemlítendő még, hogy a járműnek a súlya és az energiával ellátandó modulok száma változott, így nem meglepő a teljesítménybéli visszaesés, továbbá ez nem akadályozza a feladatai elvégzésében, finomra hangolása ennek köszönhetően még kedvezőbb.

\section{XI. ÖSZEGZÉS}

A jármü összeszerelése, tesztelése megtörtént. A kiadott utasításokat elvégzi, tesztelése során nem produkált eltérést, pontossága viszonylag nagymértékben függ a használati helytöl legyen az akár benti vagy kinti környezet, azonban a könnyű kalibrálhatóság miatt ez könnyen állítható.

A fejlesztés során meghatározott folyamatok megvalósításra kerültek, mint a könnyü kezelhetőség, többféle elérhetőség, az eddigi szükséges energia szint tartása, a sötétben való láthatóság megtartása, a könnyen értelmezhető visszajelzések, így a továbbfejlesztésre tett kísérlet sikeresnek tekinthető.

\section{KÖSZÖNETNYÍLVÁNITÁS}

A publikáció elkészítését az EFOP-3.6.1-16-2016-00022 számú projekt támogatta. A projekt az Európai Unió támogatásával, az Európai Szociális Alap társfinanszírozásával valósult meg.

A dokumentum szerkesztésében való észrevételeiért és tanácsaiért Erdei Timotei Istvánnak, a Debreceni Egyetem oktatójának.

\section{HivATKOZÁSOK}

[1] Frizting,(2018, May 20).[Online].Available: http://fritzing.org/download/0.9.2b/

[2] $\operatorname{Gimp}(2018, \quad$ May 20).[Online].Available: https://www.gimp.org/about/authors.html Spencer Kimball Peter Mattis

[3] Arduino Mega 2560 Rev3,(2018, May 20).[Online].Available: https://store.arduino.cc/arduino-mega-2560-rev3

[4] Arduino IDE,(2018, May 20).[Online].Available: https://www.arduino.cc/en/main/software

[5] N. M. A. Mohamed, Abdalgfa A. A. Abdalaziz, A. A. Ahmed,A. A. A. Ahmed," Implementation of a PID control system on microcontroller (DC motor case study), " 2017 International Conference on Communication, Control, Computing and Electronics Engineering (ICCCCEE), January 2017.

[6] L298H, (2018, May 20).[Online].Available: https://www.sparkfun.com/datasheets/Robotics/L298_H_Bridge.pdf

[7] Arduino Pulse Width Modulation, (2018, May 20).[Online].Available: https://www.arduino.cc/en/Tutorial/PWM

[8] C. M. Chirinos, V. L. Velásquez, H. A. Soto, " Power consumption reduction of an electric shower using a PWM based power supply," Central America and Panama Student Conference (CONESCAPAN), 2016 IEEE, 2016 September.

[9] HC-06 Bluetooth module,(2018, May 20).[Online].Available: http://www.fecegypt.com/uploads/dataSheet/1480849570_hc06.pdf

[10] 2004A LCD Display,(2018, May 20)https://www.betaestore.com/download/rk/RK-10290_410.pdf

[11] HC-SR04,(2018, May 20).[Online].Available: https://www.electroschematics.com/8902/hc-sr04-datasheet/

[12] S. Silva, S. Soares, A. Valente, ” Digital sound processing using arduino and MATLAB," Conference: $16^{\circ}$ Encontro Científico da Seção Portuguesa da AES, November 2012.

[13] S. Silva, S.Soares, M.Reis, P.A.A Assunção, ” A dynamic programming algorithm to select optimal high-priority voice segments using Arduino," IEEE EUROCON 2017 -17th International Conference on Smart Technologies, July 2017.

[14] D.Wolber, H.Abelson, E.Spertus, L.Looney, „App Inventor 2: Create your own Android Apps", 2014 October 03.

[15] A. Ramasami, "Accident prevention by efficient brake monitoring and controling system, " Conference: 9th National conference on Signal processing and communication technologies'18 CSPCT'18, May 2018.

[16] Code::Blocks Team, (2017, Dec, 5).Code:Blocks 16.01 [Online].Available: http://www.codeblocks.org/docs/manual_en.pdf

[17] T. I. Erdei, Zs. Molnár, N. C. Obinna, G. Husi, „Cyber Physical Systems In Mechatronic Research Centre," IMTU Oradea - Proceedings of the Annual Seesion of Scientific Papers May 25th - May 27th - 2017. 